\title{
Determination of Customer Satisfaction by Staff Demographic Properties: A Research In Recreation Sports Business
}

\author{
Abdulmenaf Korkutata \\ Correspondence: Abdulmenaf Korkutata, Sakarya University, Faculty of Tourism, Department of Tourism Management, \\ Sakarya, 54187, Turkey.
}

Received: April 5, 2017

doi:10.11114/jets.v5i6.2329

Accepted: May 3, 2017 Online Published:May 7, 2017

URL: https://doi.org/10.11114/jets.v5i6.2329

\begin{abstract}
Sport managements supply consumers with services in a number of sport branches. In the same breath sport managements (facilities) should provide customer satisfaction due to the intuition of 'client centered and service providing corporations'. In this regard, the purpose of the researcher is to analyze whether the pleasure of clients that prefer studios make them special to individual exercise training are satisfied or not according to demographic features. The research has been conducted in Private Training Studio as a case study. In this research, the questionnaire technique has been employed and applied to 100 clients that came to Private Training Studio within the scope of the research technique. This research concludes that; a difference is not observed in clients based on gender, membership period and the frequency of making benefit of the management, however the significant determinants proved to be the age of clients and the pleasure level of the management (see Table 4).
\end{abstract}

Keywords: sportive recreation, client pleasure, private training studio, pleasure from personnels

\section{Introduction}

Social and cultural activities which are in the scope of recreation make individuals develop, relax and motivate themselves. Besides, sportive recreation activities are also beneficial in psychological manner such as self knowledge, development of character and having new horizons for individuals (Hall \& Page, 2006; Karakucuk, 1999; Broadhurst, 2001). In this manner people demand to evaluate their free space that odds out of their intense working life and also renew themselves and go back to their work fit. Hence the activities that individuals want to do in their free space out of working life show differences according to individuals' income, knowledge, culture and pleasure feelings. This difference is especially observed in established special sport complexes and special sport studios recently, even individuals that want to have beneficial consequences more are getting increased by number day by day and want to work with exercise trainings made for individuals (Personal Training) by professional educators and exercise trainers special to individuals (Personal Trainer). Also a number of managements started to present activities in order to cover the intense demand that occurs in the subject at issue as mentioned above. Either the competition between managements or the factors that are effective for the evaluation of provided services made the pleasure from managements important. However when the literature is examined, the works towards sportive recreation managements are quite limited. Therefore the research at issue is considered to be contributional to the level of pleasure in sport managements.

The most important source in sport management is human being, who provides services and educates clients personally. Hence, the pleasure of clients who prefer sport managements is directly proportionate to; attitude, behavior, knowledge and skills of personnels (Chen, 2008:103; Korkutata, 2015). From this point of view, hired personnel to sport managements that can lead the management to the required level which are good persons that are qualified and well-informed in the field, presentable, giving importance to the job, developing constantly and most importantly knowing how to behave.

In this context the purpose of the work is; evaluating whether a difference occurs or not according to demographic features of the pleasure level of the clients that prefer special to personal exercise training studios. Within the scope of the purpose, the answer of the following question is elaborated on;

"Is there a difference in pleasure of clients from personnel when demographic features of clients are taken into consideration?" 


\section{Literature Search}

Sport managements (facilities) are defined sport places that provide every tool and equipment aimed at sports. One of the reasons why these sport facilities are built is to be able to give an opportunity to do sports in healthy ways to the individuals as free space activity (Ceyhun, 2008:29). In this context, sportive recreation is a branch that bases on fundamentally physical exercise or recreative purposed application of various sport branches and includes most of the recreation activities (Ramazanoglu et al., 2004:177; Zorba \& Bakır, 2004:106). Hence, sport managements that apply sportive recreation activities are special or public corporations appeal to all ages. The purpose of these kinds of corporations is to make individuals benefit from every kind of sport branches and help them to have a healthy body. Every sportive activities that are held in sport managements are also defined as free space activities (recreation) and they are the backbone of the recreation activities. Since sport is able to response all kind of recreative needs of people in all ages, sport is the most preferred activity among the recreation activities. (Karakucuk, 1999:248).

Sport is one of the most comprehensive and interesting fields of recreation. Recreation, here, has the role of spreading sports among society. With the features sport and recreation are effective to each other mutually. In areas that sports are applied as a growing and widening sector, it provides positive results for economic perspective in the context of becoming more integrated to cultural life style and natural environmental values with respect (Ustundag et al., 2011:32). Besides this, developed countries state that sportive investments have important roles in government planning (Yetim, 2000:71). Sport managements provide services to consumers with various products. At the present time, sport managements (facilities) provide client pleasure due to being client centered and service providing corporations. In this respect when demanded services are not provided in sport managements it causes loss of clients (Park \& Kim, 2000:199). But in case clients are satisfied with the services provided and education in sport branches, this led clients to prefer the management again and this situation provides a great advantage for sport managements (Gundogdu \&Devecioglu, 2009:16). Thus, the most important source in sport management is the personnel that educate clients personally. Hence, the expectation of high quality of clients makes sport managements to design qualified programs and to provide client pleasure as an obligation.

In this contex, a sport management should find and choose the personnels that are in the right amount with enough qualification and quantity to make benefit of manpower efficiently and productive for providing services and widen the horizon (Ekenci \& İmamoglu, 2002; 116-132; Baum, 2007; Singh, 1997). Because it is stated that continuity of funcitons that sport managements have and client pleasure is based upon the quality of personnel (Mayaka \& Akama, 2007; Zegonari, 2009). Besides, to provide good quality services, experienced, expert, well-educated and qualified human resources for hiring personnel (Brotherton, 1994; Ceyhun, 2008:331). Besides all these, in the consequence of hygiene factor which affects clients' perception being cared by owners or directors of these service providing managements (Thwaites \& Chadwick, 2005:332), management would reach the results about client pleasure and provided services by them.

Pleasure is defined as a response to the anticipated services by clients. Hence, Akın et al., (2013), stated the condition of pleasure as individuals live pleasure when in the state of being attached to others, belonging feelings and in social circumstances. Formation of self reliance is stated by Ozguven (2008:657) to occur in accordance with the expectations of clients with purchased products or services, satisfaction or disssatisfaction of the client is stated by Turk (2005:198) as occured with the quality of purchased products or services. So the main purpose of examining client pleasure is to provide continuity or permanence between management and seller or to commerce with product or service (Bayuk \& Kucuk, 2007:290). In this regard, it can be said that pleasure is provided with response to clients' emotions and thoughts and providing services duly.

Client pleasure carries a great importance in sport managements similar to every management. Because sport managements that respond to every need and demand of clients are able to carry on within the remaining sector but the ones that are not able to respond every need and demand of clients and do not develop their selves are about to fade away. Thus sport managements need to create new trends in need of the circumstances at the present time. Because, day by day tools and equipment that are used in the lessons take place in sport managements are changing so the education systems accordingly need to renew their selves in line with this. Thus, this change should reflect the need and demand of clients. Within that period, only the sport managements that develop their selves and that provide services based on the remaining time requirements to clients will be preferred more. Because in this kind of sectors, to provide customer satisfaction is the only way to be survive.

\section{Method}

\subsection{Sampling of the Research}

The study is conducted in Private training studio as sample survey. Private training Studio is a sport management which is established with the principle of personal training only. Besides it has the functions of a gym that develops 
training schedules to avoid sport injuries and fitness equipment. The purpose of the management is to create schedules aimed at diseases that affect human anatomy and to offer fitness solutions to the aim controlled by expert trainers. Private training has the same meaning in Turkish as well. There are many corporations and foundations which also have the same name in Europe and the World. However, the new understanding and trend in fitness sector consists of special training systems based on Personal training system. This system is built in a fast way and preferred by individuals whose income is higher than middle class and way higher than European standards. The management was established as a private company in 2012 and run by the owner. It is settled in Etiler, Istanbul. Within the scope of the management, every month 100 people are getting education by expert personel who completed their national and international education.

In the research, 100 clients that come to Private training Studio were being applied questionnaire technique. In the first section demographic information, and in the second section 19 statements that measure customer satisfaction by questioning attitude, behaviour, knowledge and skills of personnel are used with Likert scale which was developed by Chen (2008:131). The 19 statement are occured as 0,870 in Cronbach's Alpha Value. This value is really reliable as easy to say. In this context the hypotheses are tested to answer the research question:

$\mathbf{H}_{\mathbf{1}}$ : There is a differentiation in client's pleasure level from personnel based on client gender.

$\mathbf{H}_{2}$ : There is a differentiation in client's pleasure level from personnel based on client age.

$\mathbf{H}_{3}$ : There is a differentiation in client's pleasure level from personnel based on client membership currency.

$\mathbf{H}_{4}$ : There is a differentiation in client's pleasure level from personnel based on client beneficial frequency.

\section{Findings}

In this section it will benefit from the purpose of the research and the evidence analyzed towards the hypotheses and the research questions. With the data, frequency analysis towards demographic information and analysis of t-test, ANOVA Test towards pleasure level from personnel will be evaluated.

Table 1. Demographic Features of The Clients Participated In Research

\begin{tabular}{|c|c|c|c|c|c|}
\hline Variable & Number & Percent(\%) & Varience & Number & Percent $(\%)$ \\
\hline \multicolumn{3}{|l|}{ Gender } & \multicolumn{3}{|l|}{ Marital Status } \\
\hline Male & 15 & 15 & Married & 19 & 19 \\
\hline Female & 85 & 85 & Bachelor & 81 & 81 \\
\hline Total & 100 & 100 & Total & 100 & 100 \\
\hline \multicolumn{3}{|l|}{ Age } & \multicolumn{3}{|l|}{ Education Status } \\
\hline Aged 30 and younger & 19 & 19 & High School and Equal & 6 & 6 \\
\hline Between Ages 31-35 & 60 & 60 & Associate Degree & 4 & 4 \\
\hline Between Ages 36-40 & 10 & 10 & Undergraduate & 26 & 26 \\
\hline Aged 41 and older & 11 & 11 & Master/Doctoral Degree & 64 & 64 \\
\hline Total & 100 & 100 & Total & 100 & 100 \\
\hline \multicolumn{3}{|l|}{ Income Status } & \multicolumn{3}{|l|}{ Frequency of Appearance } \\
\hline Turkey Standards & 16 & 16 & Everyday & 2 & 2 \\
\hline Higher than Turkey Standards & 29 & 29 & Once a week & 9 & 9 \\
\hline Way Higher than Turkey Standards & 55 & 55 & Thrice a week & 86 & 86 \\
\hline \multirow{2}{*}{ Total } & \multirow{2}{*}{100} & \multirow{2}{*}{100} & Once every 15 days & 3 & 3 \\
\hline & & & Total & 100 & 100 \\
\hline
\end{tabular}

When the participants' gender are evaluated in the research; most of them are women (\%85) and men are minority (\%15). With the consequences; it is women mostly want to do sports with special trainers clearly. When the participants' ages evaluated, it is found that mostly individuals aged between 31-35 (\%60) prefer special trainers, followed by aged 30 and younger and six-aged groups (\%19). Hence it is mostly young population that prefers studios which apply personal training and exercise schedules and want to do sports in the lead of personal trainers. When marital status of 
the participants that prefers studios that apply personal training and exercise schedules are observed, most of them are bachelors (\%81). When the participants' education status are evaluated, it is found that mostly individuals with master and doctoral degrees (\%64) prefer studios that apply personal training and exercise schedules, followed by undergraduate individuals that graduated (\%26). This results show us that individuals with higher level of education have more tendency to a healthy life. When the participants' (which prefer studios that apply personal training and exercise schedules) income status are evaluated it is found that most of them are way higher than Turkey standards (HTS) (\%29) and higher than Turkey standards (WHTS) (\%55). In this context, it is possible to say that there is a significant relation between income of individuals, personal training and exercise schedules with doing sports in the lead of special trainers. When frequency of appearance of individuals that prefer studios that apply personal training and exercise schedules are evaluated, it is observed that most preferred program is thrice a week Schedule (\%86).

Table 2. Order of Priority of Management Usage Purpose

\begin{tabular}{|c|c|c|c|c|}
\hline \multirow{3}{*}{ Variable } & \multicolumn{4}{|c|}{ Significance Level } \\
\hline & 1st Degree & 2nd Degree & 3rd Degree & Out of Value \\
\hline & $\mathbf{N}$ & $\mathbf{N}$ & $\mathbf{N}$ & $\mathbf{N}$ \\
\hline Making use of free space & 14 & - & 2 & 84 \\
\hline Maintaining a healthy life & 70 & 24 & 3 & 3 \\
\hline Having a beautiful and healthy body & 11 & 48 & 11 & 30 \\
\hline Avoiding weight issue & 1 & 21 & 38 & 40 \\
\hline Let off .steam & 4 & 7 & 37 & 52 \\
\hline Developing social relations & - & - & 9 & 91 \\
\hline
\end{tabular}

When the answers to the question about the purpose of management usage is evaluated, the members to personal training and exercise schedules mostly prefer the studios with the purpose of maintaining a healthy life (\%70), following the will of having a beautiful and healthy body (\%48) and, avoiding weight (\%38). Hence it is possible to say that it is a key factor for individuals to maintain a healthy life in need and besides living beautifully and in a healthy way, physical appearance is also adopted by the participants mostly.

Table 3. Differentiation Based On Gender For Clients’ Pleasure Level From Managements

\begin{tabular}{llllllll}
\hline & Gender & Average & S.D & Average Difference t- Value Significance \\
\hline \multirow{2}{*}{ Attitude-Behaviour-Knowledge and Experience } & Male & 4,8667 & 0,28312 & & & \\
& & & & & & & \\
& Female & 4,9980 & 0,01808 & & $-4,13137$ & 0,000 & $\mathbf{0 , 0 9 4}$ \\
\hline
\end{tabular}

For the relationship between gender and customer satisfaction from managements, t-test is applied. Gender and the client pleasure level between plant $t$-test has been performed. Level of satisfaction with their property according to gender, it is observed that in the study male $(4,8667)$ and women $(4,9980)$ averages are close to one another. This is why business client pleasure level when it comes to sex; customers satisfaction level between businesses $(0,094>0.005)$ there is no significant difference. Therefore, "there is a differentiation between their sex and consumer satisfaction levels (H1)" hypothesis is rejected. 
Table 4. Level of Satisfaction with Their Property According to Their Age Difference

\begin{tabular}{|c|c|c|c|c|c|}
\hline Measure & Variable & Average & $\begin{array}{l}\text { Standard } \\
\text { Deviation }\end{array}$ & $\begin{array}{l}\text { F } \\
\text { Value }\end{array}$ & Significance \\
\hline \multirow{4}{*}{$\begin{array}{l}\text { Attitude-Behaviour-Knowledge and Experience } \\
* * *\end{array}$} & Age 30 and under & $\begin{array}{l}4,702 \\
5\end{array}$ &, 04567 & \multirow{4}{*}{16,210} & \multirow{4}{*}{0,000} \\
\hline & Between 31-35 & $\begin{array}{l}4,722 \\
2\end{array}$ & ,00000 & & \\
\hline & Between 36-40 & $\begin{array}{l}4,684 \\
7\end{array}$ & ,07053 & & \\
\hline & $\begin{array}{l}\text { Age } 41 \text { and } \\
\text { older* }\end{array}$ & $\begin{array}{l}4,494 \\
9\end{array}$ & ,29550 & & \\
\hline
\end{tabular}

* Difference between the two groups (30 years of age and six to 41 and higher), (31-35 age - 41 and above), and Age (36-40- 41 and above) is due to the difference between groups.

** That makes sense that produces different groups Schefe POST-HOC tests by looking at results has been detected.

Customers who participate in Research between their responses to whether there is a meaningful difference to the analysis, the other is through an ANOVA. With ANOVA Test customers satisfaction levels between ages a meaningful difference in whether or not is measured. ANOVA Test results according to the results obtained with age customers who participate in research to satisfy business differentiation between levels of ownership as seen in 41-years and older customers with satisfaction levels (Attitude, Behaviour, Knowledge and Experience) $<0.005(0.000)$ that makes sense as it is a difference that is. Therefore, the age of customers between consumer satisfaction levels have a meaningful differentiation so $\left(\mathrm{H}_{2}\right)$ hypothesis is accepted.

By the time their customers satisfaction with business-level differentiation between these variables stand in a different ANOVA test was performed and the membership by the time a differentiation between satisfaction level has not been found. This is the reason why $\mathrm{H}_{3}$ hypothesis is rejected.

Customers benefit from businesses with frequency is pleased to stand-level differentiation between one another to ANOVA test has been carried out as a result of this analysis, but any differentiation is identified that refers to the $\mathbf{H}_{\mathbf{4}}$ hypothesis is rejected.

\section{Discussion}

Private Training Studio which is at the same time a one-to-one training program is applied to a business is mostly preferred by people who do not suffer from money shortages. There have been many other Private Training Studios. In addition, there are experts in multi-branch staff on the studio. Our investigation implies that health factor is the most important reason, which is similar with the work of Gungormus and the form of savings deposits also matter (2014:383). The profile of people who mostly prefer this type of business is very young and single ladies. This result seems similar with the work of Chen (2008:65), and Gungormus form of savings deposits. (2014:378-379). This is not surprising. Our investigation has also found that one of the reasons to become a member this type business is the will of "stay beautiful and healthy" The social widespread social opinion that Women value for their external appearance overlaps with the results of our research. However, when a health club membership is taken into account, other reasons why other age and gender groups don't appreciate the importance of value of this type of membership is complicated.

The quality and the quantity of the personnel of these enterprises are required in order to satisfy customer expectations. (Ekenci and İmamoglu, 2002: 116-132; Baum, 2007; Singh, 1997). In fact, business activities by providing high level of customer satisfaction keep quality staff (Mayaka and Akama, 2007; Zagonari, 2009 ). Especially in Personal Training service that provides a Private Training Studio as a customer-service features for business, the staff more to the forefront. Europe and the world there are many institutions and organizations established with this name. However, fitness industry trends and understanding new Personal Training system based on the specific training systems. This system currently has spread rapidly and more preferred than Europe by people who has more purchasing power. In fact, study found that most of the customers as a result of the analysis is on top of Turkey and the Turkish standards as it is individuals that are above has been detected. In that context, the individual's income status is closely correlated with their choice of specific training and a special request to make sports by coaches. It comes with a high level of working life which is very busy and stressful. Given that the routing of discharge will empty themselves in their lives and the business to adapt to beat; therefore, they do prefer special education and luxury sports business. This common social opinion overlaps with the result of our research. Therefore, it is possible to say this research contributes to the literature which elaborates on why sport facilities providing training by private couches are preferred. 


\section{References}

Akın, A., Uysal, R., \& Citemel, N. (2013). Sosyal Guvende Hissetme ve Memnuniyet Olceginin Turkce Formunun Gecerlik ve Guvenirlik Calısması, Egitim Fakultesi Dergisi, 9(1)1, 1-40.

Baum, T. (2007). Human Resources in Tourism: Still Waiting for Change. Tourism Management, 28, 1383-1399. https://doi.org/10.1016/j.tourman.2007.04.005

Bayuk, N., \& Kucuk, F. (2007). Müşteri Tatmini ve Müsteri Sadakati İliskisi. Marmara Üniversitesi İ.I.B.F. Dergisi, 22(1), 285-292.

Broadhurst, R. (2001). Managing Environments for Leisure and Recreation. New York: Routledge. https://doi.org/10.4324/9780203457306

Ceyhun, S. (2008). Spor Tesislerinin Rekreatif Acıdan Kullanımı. Kastamonu Egitim Dergisi, 16(1), 325-332.

Chen, T. (2008). The Examınatıon Of Factor That Affect The Relatıonshıp Between Employee-Customer Satısfaction In Recreatioonal Sport/Fitness Clubs In Taiwan. Doctor of Education, United States Sports Academy.

Ekenci, G., \& İmamoglu, A. F. (2002). Spor İsletmeciligi. Nobel Yayın Dagıtım, Ankara.

Gundogdu, C., \& Devecioglu, S. (2009). Spor İsletmelerinde İnsan Kaynakları Planlaması. e-Journal of New World Sciences Academy, 4(1), 10-20.

Gungormus, H. A., Yenel, F., \& Gurbuz, B. (2014). Bireyleri Rekreasyonel Egzersize Guduleyen Faktorlerin Belirlenmesi: Demografik Farklılıklar. International Journal of Human Sciences. 11(1), 373-386. https://doi.org/10.14687/ijhs.v11i1.2165

Hall, C. M., \& Page, S. J. (2006). The Geography of Tourism and Recreation. New York: Routledge. https://doi.org/10.4324/9780203420249

Karakucuk, S. (1999). Rekreasyon. Ankara: Bagırgan Yayım evi.

Korkutata, A. (2015). Antalya'da 4 ve 5 Yıldızlı Otellerde Sunulan Rekreatif Amaçlı Animasyon Faaliyetlerinin Müsteri Memnuniyetine Etkisi. Yayınlanmamıs Doktora Tezi. Sakarya Universitesi Sosyal Bilimler Enstitüsü. Sakarya.

Mayaka, M., \& J. S. A. (2007). Systems Approach to Tourism Training and Education: The Kenyan Case Study. Tourism Management, 28(1), 298-306. https://doi.org/10.1016/j.tourman.2005.12.023

Ozguven, N. (2008). Hizmet Pazarlamasında Müsteri Memnuniyeti ve Ulaştırma Sektörü Üzerinde Bir Uygulama. Ege Akademik Bakış, 8(2), 651-682. https://doi.org/10.21121/eab.2015221927

Park, S., \& Kim, Y. (2000). Conceptualizing and Measuring the Attitudinal Loyalty Construct in Recreational Sport Contexts. Journal of Sport Management, 14(3), 197-207. https://doi.org/10.1123/jsm.14.3.197

Ramazanoglu, F., Altungul, O., \& Ozer, A. (2004). Sportif Acıdan Rekreasyon Etkinliklerinin Degerlendirmesi. Dogu Anadolu Bolgesi Arastırmalart, 176-179.

Singh, S. (1997). Developing Human Resources for the Tourism Industry with Reference to India, Tourism Managemet, 18(5), 299-306. https://doi.org/10.1016/s0261-5177(97)00018-6

Thwaites, D., \& Chadwick, S. (2005). Service Quality Perspectives in Sport Tourism. Sport in Society, 8(2), 321-337. https://doi.org/10.1080/17430430500087781

Turk, M. (2005). Perakendeci İsletmelerde Personelin Davranıssal Ozellikleri İle Müsteri Memnuniyeti Arasındaki İliski. Suleymen Demirel Universitesi, İktisadi ve İdari Bilimler Fakultesi, 10(10), 195-219

Ustundag, O., Devecioglu, S., \& Akarsu, E. E. (2011). Spor ve Rekreasyon Alanlarının Sehir Planlamasındaki Yeri ve Önemi. 6th International Advanced Technologies Symposium (IATS'11). 16-18 May, Elazıg, 31-34.

Yetim, A. A. (2000). Sporun Sosyal Gorunumu. Gazi Beden Egitimi Spor Bilimleri Dergisi, V(1), 63-72.

Zagonari, F. (2009). Balancing Tourism Education and Training. International Journal of Hospitality Management, 28(1), 2-9. https://doi.org/10.1016/j.ijhm.2008.03.006

Zorba, E., \& Bakır, M. (2004). Serbest Zaman Kavramı. Sporda Sosyal Alanlar Secme Konular 1. Ed: Ramazanoglu F., Bıcaklar Kitabevi, Ankara.

\section{Copyrights}

Copyright for this article is retained by the author(s), with first publication rights granted to the journal.

This is an open-access article distributed under the terms and conditions of the Creative Commons Attribution license which permits unrestricted use, distribution, and reproduction in any medium, provided the original work is properly cited. 